Article

\title{
A Study on Reduction of Copper Smelting Slag by Carbon for Recycling into Metal Values and Cement Raw Material
}

\author{
Jei-Pil Wang * and Urtnasan Erdenebold $(\mathbb{D}$ \\ Department of Metallurgical Engineering, School of Engineering, Pukyong National University, Busan 608-739, \\ Korea; ebold1111@pukyong.ac.kr \\ * Correspondence: jpwang@pknu.ac.kr; Tel.: +82-51-629-6341
}

Received: 15 December 2019; Accepted: 7 February 2020; Published: 14 February 2020

\begin{abstract}
Copper smelting slag is a solution of molten oxides created during the copper smelting and refining process, and about 1.5 million tons of copper slag are generated annually in Korea. The oxides in copper smelting slag include ferrous $(\mathrm{FeO})$, ferric oxide $\left(\mathrm{Fe}_{2} \mathrm{O}_{3}\right)$, silica $\left(\mathrm{SiO}_{2}\right.$ from flux), alumina $\left(\mathrm{AI}_{2} \mathrm{O}_{3}\right)$, calcia $(\mathrm{CaO})$ and magnesia $(\mathrm{MgO})$. The main oxides in copper slag, which are iron oxide and silica, exist in the form of fayalite $\left(2 \mathrm{FeO} \cdot \mathrm{SiO}_{2}\right)$. Since copper smelting slag contains high content of iron, and copper and zinc, common applications of copper smelting slag can be used in value-added products such as abrasive tools, roofing granules, road-base construction, railroad ballast, fine aggregate in concrete, etc. Some studies have attempted to recover metal values from copper slag. This research was intended to recover ferrous alloy contained $\mathrm{Cu}$, a raw material of zinc, from copper slag, and produce reformed slag such as blast furnace slag for Portland cement. As a result, it was confirmed that with reduction smelting by carbon at temperatures above 1400 ${ }^{\circ} \mathrm{C}$, it is possible to recover pig iron containing copper from copper smelting slag, and the addition of $\mathrm{CaO}$ in reduction smelting helped to reduce iron oxide in the fayalite and change the chemical and mineralogical composition of the slag. The copper oxide in the slag can be easily reduced and dissolved in the molten pig iron, and zinc oxide is also reduced to a volatile zinc, which is removed from the furnace as fumes, by carbon during the reduction process. When $\mathrm{CaO}$ addition is above $5 \%$, acid slag is completely transformed into calcium silicate slag and is observed to be like blast furnace slag.
\end{abstract}

Keywords: copper smelting slag; pig iron; fayalite; recovery

\section{Introduction}

Since the beginning of the Industrial Revolution, byproducts such as the metallurgical slag left over when metals are produced from natural and secondary raw materials have been considered waste. Copper slag is produced during the manufacturing of copper, and for every ton of copper production about 2.2 tons of copper slag are generated, and 1.5 million tons of copper slag are generated in Korea every year [1-5]. Dumping or disposal of copper slag causes wastage of metal values and leads to environmental problems. In particular, dumping requires a wide area and leads to many negative impacts such as eroding and damaging land surfaces, and solid and gas substances polluting the atmosphere [6]. South Korea has a small land area and a high population. Therefore, South Korea refuses to landfill metallurgical slags and promotes zero waste with the reuse and recycling of these waste materials. Recently, scientists around the world have paid special attention to recycling the copper slag and have developed several technologies. The common management options for copper slag are recycling for the production of value-added products such as abrasive tools, roofing granules, 
cutting tools, abrasives, tiles, glass, road-base construction, railroad ballast, and asphalt pavement. The potential uses of copper slag are a partial substitute in cement and aggregate in concrete $[7,8]$. Nevertheless, these methods cannot efficiently recover a high content of iron and valuable metal in copper smelting slag.

Copper slag differs by chemical composition and structure, depending on the type of processing. Copper smelting slag usually contains about $1 \%$ copper and $40 \%$ iron depending on the initial ore quality and furnace type. Significant amounts of $\mathrm{SiO}_{2}, \mathrm{FeO}, \mathrm{CaO}, \mathrm{Al}_{2} \mathrm{O}_{3}$ and minor amounts of other elements (e.g., zinc, titanium, and lead) are also associated with copper slag [9]. The main components of copper slag are iron oxide and $\mathrm{SiO}_{2}$, and these exist in copper slag mainly in the form of fayalite $\left(2 \mathrm{FeO} \cdot \mathrm{SiO}_{2}\right)$.

The processing technologies differ depending on the metals to be recovered from copper slag. Hydrometallurgical treatment is widely used for the recovery of copper slag, including direct leaching in sulfuric acid, and leaching in sulfuric acid through $\mathrm{H}_{2} \mathrm{~S}$ gas or ferric chloride [10,11]. However, leaching of copper slag may be too expensive because it requires milling costs for leaching, and high consumption of strong acid and reagents. Moreover, the concentrates need to be processed for refining, and it is also very toxic.

Magnetic separation and the reduction smelting method are used to recover and separate iron from copper slag. Physical separation is an appropriate method for the recovery of iron from copper slag, but the recovery rate with magnetic separation is lower by about $40 \%$ due to its difficult processing of fayalite. Therefore, most studies have conducted roasting-magnetic separation to recover iron from the copper slag, and the recovery rate with this method obtained about $80 \%$ [12-14]. The roasting-magnetic process involves a reduction process by a reducing agent and converting from the main phase as fayalite to calcium silicates and magnetite by mixing fluxes as $\mathrm{CaO}$ added at a high temperature of about $1050-1300{ }^{\circ} \mathrm{C}[15,16]$, and then magnetic separation is used to recover iron from roasted slag after a cooling process. Roasting-magnetic separation is a feasible method for the recovery of iron, but it also demands energy consumption for milling and roasting to improve the recovery of iron, and for iron concentrate to be next treatment, hence incurring a higher production cost. Additionally, heating energy is lost through the cooling process after roasting and several iron losses are associated with residues as the non-magnetic parts, which are considered waste again.

Although reduction smelting requires a large amount of energy during the smelting process, it is possible to recover $\mathrm{Fe}$ and $\mathrm{Cu}$ as a form of iron alloy with alloying elements such as $\mathrm{Cu}, \mathrm{Mn}$ and $\mathrm{Si}$ from the copper slag. Mn and Si are main constituents, and iron carbide (cementite) is also present in most steel and cast iron. Carbon from reducing agent can be formed to inform of iron carbide in the ferrous alloy during reduction smelting for the recovery of iron from copper slag. Copper is used as an additive element to improve mechanical properties such as hardness, abrasion resistance and corrosion resistance in cast iron products $[17,18]$.

Therefore, our study focused on zero waste recycling in the manufacture of foundry pig iron with $\mathrm{Cu}$ content from copper slag using high-temperature reduction smelting and investigated the utilization of byproducts such as reformed slag, and furnace ash containing zinc that is generated during the reduction smelting of copper slag, which can have economic benefits. Byproducts such as furnace ash containing zinc and reformed slag give additional value to recycling with the recovery of zinc and preparation of value-added product such as cement raw material, respectively.

\section{Materials and Methods}

\subsection{Experimental Materials}

In this study, waste copper slag from G Company was used. The molten slag was rapidly quenched in cool water, and consequently, the cooling rate tended to obtain a glassy phase, and the slag was ground for further applications. Mineralogical analysis of the slag was determined by X-ray diffractometer as the model of Rigaku UltimaIV has the $3 \mathrm{kw} \mathrm{Cu}-\mathrm{K} \alpha \mathrm{X}$-ray tube. Figure 1 shows 
the results of XRD analysis of the copper smelting slag. XRD data collection of the slag sample was conducted with a scanning range of 10 to $90^{\circ}$ and a time of $10 \mathrm{~min}$ with a step size of $0.02^{\circ}$. Although peaks of peculiar to amorphous phase of glass were indicated, several peaks of fayalite $\left(2 \mathrm{FeO} \cdot \mathrm{SiO}_{2}\right)$ and monticellite $\left(\mathrm{CaMgSiO}_{4}\right)$ were observed. XRF spectrometer was a Shimadzu XRF-1700 X-ray fluorescence spectrometer. X-ray fluorescence $(\mathrm{XRF})$ is known that it is a non-destructive analytical technique used to determine the elemental composition of materials as the metal, glass, ceramic and building materials. The sample was placed inside a platinum crucible and loaded into an XRF machine, where in XRF machine, the beam was loaded into the sample holder, after which, the sample was ionized by $x$-rays under vacuum medium. Then, fluorescent $x$-rays were analyzed and compared with certified references and calculated by XRF OXSAS software. Table 1 shows the result of XRF analysis of the particles of the copper slag which indicated that it consists of about $40 \% \mathrm{Fe}_{2} \mathrm{O}_{3}$, about $21 \% \mathrm{SiO}_{2}$, and $16 \% \mathrm{CaO}$, and about $7 \% \mathrm{Al}_{2} \mathrm{O}_{3}$.

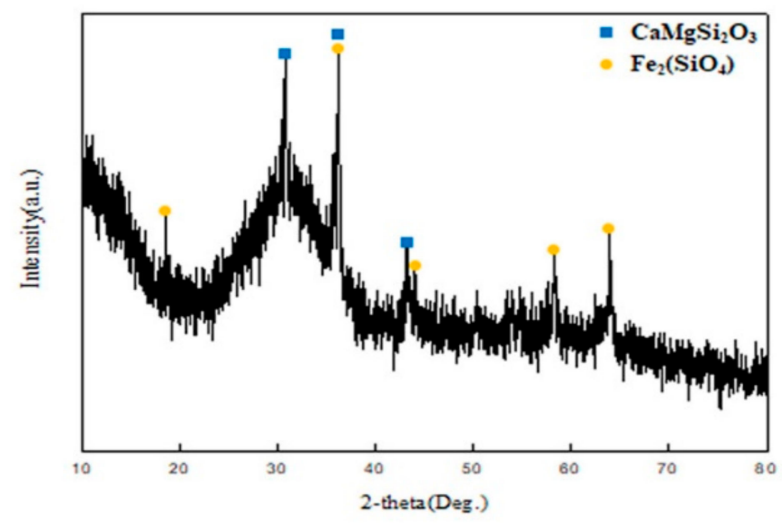

Figure 1. XRD pattern of copper smelting slag.

Table 1. The chemical composition of copper smelting slag.

\begin{tabular}{lccccccccccccc}
\hline Element & $\mathrm{Fe}_{2} \mathrm{O}_{3}$ & $\mathrm{SiO}_{2}$ & $\mathrm{CaO}$ & $\mathrm{Al}_{2} \mathrm{O}_{3}$ & $\mathrm{ZnO}$ & $\mathrm{MgO}$ & $\mathrm{CuO}$ & $\mathrm{MnO}$ & $\mathrm{P}_{2} \mathrm{O}_{5}$ & $\mathrm{Na}_{2} \mathrm{O}$ & $\mathrm{TiO}_{2}$ & $\mathrm{~K}_{2} \mathrm{O}$ & $\mathrm{Cr}_{2} \mathrm{O}_{3}$ \\
\hline $\begin{array}{c}\text { Content, } \\
\%\end{array}$ & 38.51 & 21.17 & 16.25 & 7.75 & 6.27 & 2.61 & 2.09 & 1.34 & 1.11 & 1.02 & 0.72 & 0.58 & 0.58 \\
\hline
\end{tabular}

\subsection{Experimental Apparatus}

Reduction smelting experiments were performed in a high-frequency induction furnace. A high-frequency induction furnace was a type of $10 \mathrm{KW}$ with melt size $10 \mathrm{~kg}$ of steel. The high-frequency induction furnace consisted of a cooler, controller and heater box. The installation space was small and additional equipment such as a dust collector was miniaturized to reduce the difficulty and cost of the process. The temperature controller was installed with the induction furnace; it regulated the furnace temperature by physical quantity of a voltage or resistance and outputs. The temperature indicating controller was a digital temperature controller of model NOVA SP79 series including a B type of thermocouple. Figure 2 is a schematic diagram of a heater box with high-frequency induction. The heater box enclosed the equipment and eliminated dust and flue gases from the furnace. Electricity was conducted through a thermo-generator using a graphite crucible, which was placed inside the heater box, and the temperature was measured using a B type thermocouple. 


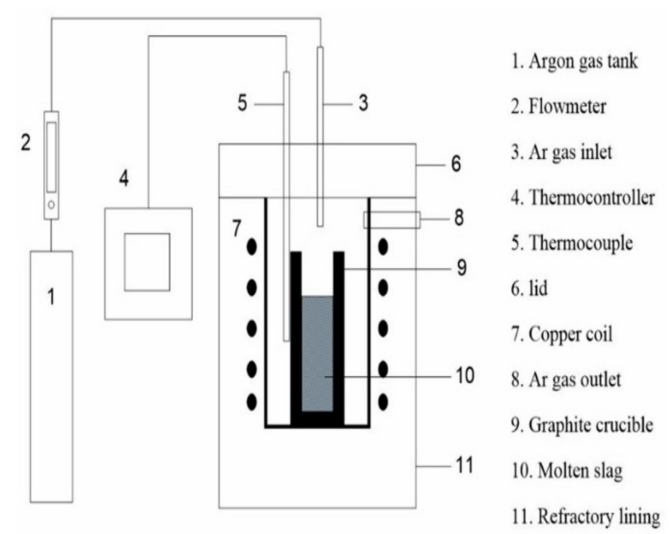

Figure 2. Schematic diagram of experimental apparatus.

\subsection{Experimental Procedures}

For the experimental process, copper slag with fine irregularities of $1 \mathrm{~mm}$ to $3 \mathrm{~mm}$ and reducing agent activated carbon were mixed with the sample at a ratio of $9 \mathrm{~g}$ per $100 \mathrm{~g}$, and then charged in a carbon crucible. The addition of $\mathrm{CaO}$ was 5, 10, 15, 20 and $25 \mathrm{~g}$ per $100 \mathrm{~g}$ of copper slag with the ratio $\mathrm{B}$ $=\% \mathrm{CaO} / \% \mathrm{SiO}_{2}=0.8,0.9,1.0,1.1$ and 1.2 . The experiment was conducted at a necessary temperature of $1600{ }^{\circ} \mathrm{C}$ for $180 \mathrm{~min}$ and reduction smelting continued for $30 \mathrm{~min}$ of holding. Then the slags were left inside the furnace to cool down to room temperature naturally. Ar gas was introduced at a rate 300 $\mathrm{cc} / \mathrm{min}$ during the process. In this experiment, when copper slag was smelted at high temperatures up to $1600{ }^{\circ} \mathrm{C}, \mathrm{Fe}_{2} \mathrm{O}_{3}, \mathrm{CuO}$ and some oxides were reduced and formed a metal phase as molten pig iron while unreduced oxides such as $\mathrm{SiO}_{2}, \mathrm{CaO}$, and $\mathrm{Al}_{2} \mathrm{O}_{3}$ etc., formed to the reformed slag, and this slag floated on the molten pig iron.

\section{Results and Discussion}

\subsection{Reduction Smelting for Ironmaking}

The reduction smelting experiments on the recovery of iron from copper slag were performed by reduction agent carbon at high temperatures under holding temperature and holding time factors. In the reduction smelting process of copper slag, iron oxide might be reduced from the decomposition of fayalite by direct reduction with solid carbon and indirect reduction with $\mathrm{CO}$ gas following this reaction:

$$
\begin{gathered}
\mathrm{Fe}_{2} \mathrm{SiO}_{4}+\mathrm{CO}=2 \mathrm{Fe}+\mathrm{SiO}_{2}+\mathrm{CO}_{2} \\
\mathrm{FeO}+\mathrm{CO}=\mathrm{Fe}+\mathrm{CO}_{2} \\
\mathrm{Fe}_{2} \mathrm{SiO}_{4}+2 \mathrm{C}=2 \mathrm{Fe}+\mathrm{SiO}_{2}+2 \mathrm{CO} \\
\mathrm{FeO}+\mathrm{C}=\mathrm{Fe}+\mathrm{CO}
\end{gathered}
$$

The copper slag used in this study contained $16 \% \mathrm{CaO}$. Therefore, it was considered that slag consists of $\mathrm{Fe}_{2} \mathrm{SiO}_{4}$ (fayalite), $\mathrm{Ca}_{2} \mathrm{SiO}_{4}$ (calcium orthosilicate), $\mathrm{CaFeSiO}_{4}$ and $\mathrm{Fe}_{2} \mathrm{O}_{3}[14,15]$. CaO affects the decomposition of fayalite and reduction of iron oxide, and changes the chemical composition of slag. Copper oxide can be easily reduced and also dissolved into a molten metal phase (as shown reaction 6), and zinc oxide is reduced to a volatile zinc, which is removed from the furnace as fumes, by carbon at a temperature of $980 \sim 1000{ }^{\circ} \mathrm{C}$ during the reduction process.

$$
\begin{gathered}
\mathrm{Fe}_{2} \mathrm{SiO}_{4}+2 \mathrm{CaO}+2 \mathrm{C}=\mathrm{Ca}_{2} \mathrm{SiO}_{4}+2 \mathrm{Fe}+2 \mathrm{CO} \\
\mathrm{CuO}+\mathrm{CO}=\mathrm{Cu}+\mathrm{CO}_{2}
\end{gathered}
$$


The reduction behavior of iron oxide reduced from fayalite decomposition was examined by thermodynamic analysis using HSC 5.1 chemistry software. It determined that, as in the results of the thermodynamic analysis in Figure 3, iron can be reduced from the decomposition of fayalite in the reduction smelting process at high temperatures above $1400^{\circ} \mathrm{C}$, and moreover, due to the impact of $\mathrm{CaO}$, the reduction of iron in fayalite is more intensified. As illustrated, $\mathrm{CuO}$ can be reduced by $\mathrm{CO}$ gas at low temperatures, as is shown in Figure 3.

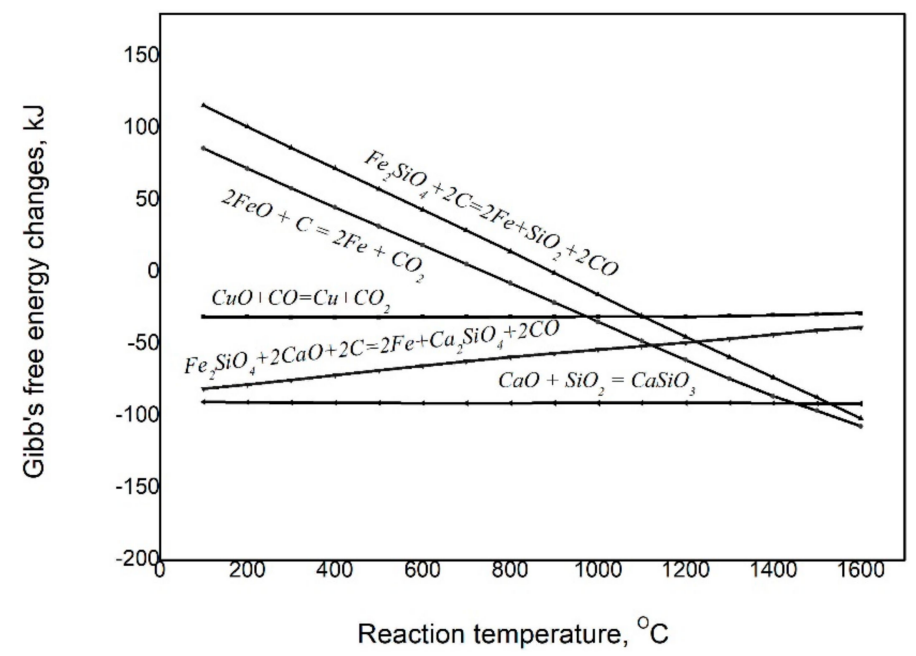

Figure 3. Gibb's free energy changes of reduction of components in copper slag by reducing carbon.

In the reduction smelting experiment with carbon additives, $\mathrm{Fe}$ and $\mathrm{Cu}$ completely reduced from the slag and then formed a metal phase, separated by the specific gravity difference with the slag consisting of $\mathrm{SiO}_{2}, \mathrm{CaO}, \mathrm{Al}_{2} \mathrm{O}_{3}$, etc., at $1600{ }^{\circ} \mathrm{C}$ for $30 \mathrm{~min}$ of holding. Additionally, the reformed slag with a relatively specific gravity floated on the molten pig iron. Table 2 shows the XRF results of the chemical composition of the reformed slag separated from copper slag by high temperature reduction according to the change of the reaction temperature condition for $30 \mathrm{~min}$ of holding. The main constituent elements were measured such as oxides of $\mathrm{SiO}_{2}, \mathrm{CaO}$ and $\mathrm{Al}_{2} \mathrm{O}_{3}$. The iron oxide content in the slag decreased from $24.62 \%$ to $16.13 \%$ according to the increasing reaction temperature from $1400{ }^{\circ} \mathrm{C}$ to $1500^{\circ} \mathrm{C}$. At a reaction temperature of $1600^{\circ} \mathrm{C}$, Fe in the slag could not be measured, indicating complete separation from the slag. The recovery rate of pig iron varied greatly depending on the reaction temperature. As shown in Table 3, it was found that the $\mathrm{Fe}_{2} \mathrm{O}_{3}$ content in the slag was decreased according to the increasing reaction time when the reaction time was $30 \mathrm{~min}$, and $\mathrm{Fe}_{2} \mathrm{O}_{3}$ was not detected, whereas $\mathrm{SiO}_{2}, \mathrm{CaO}$ and $\mathrm{Al}_{2} \mathrm{O}_{3}$ contents increased. The $\mathrm{Cu}$ content in the slag was not detected because it was completely dissolved into molten pig iron. Furthermore, $\mathrm{ZnO}$ was removed with the furnace gas while smelting of copper slag.

Table 2. Chemical composition of reformed slag separated from copper slag using high temperature reduction according to the change of the reaction temperature condition analyzed by XRF.

\begin{tabular}{cccccccccc}
\hline \multirow{2}{*}{ Reaction Temperature, ${ }^{\circ} \mathbf{C}$} & \multicolumn{10}{c}{ Element, \% } \\
\cline { 2 - 10 } & $\mathbf{S i O}_{\mathbf{2}}$ & $\mathbf{C a O}$ & $\mathbf{F e}_{\mathbf{2}} \mathbf{O}_{\mathbf{3}}$ & $\mathbf{A l}_{\mathbf{2}} \mathbf{O}_{\mathbf{3}}$ & $\mathbf{M g O}$ & $\mathbf{N a}_{\mathbf{2}} \mathbf{O}$ & $\mathbf{K}_{\mathbf{2}} \mathbf{O}$ & $\mathbf{T i O}_{\mathbf{2}}$ & $\mathbf{C r}_{\mathbf{2}} \mathbf{O}_{\mathbf{3}}$ \\
\hline $\mathbf{1 4 0 0}$ & 35.20 & 19.80 & 24.62 & 13.07 & 2.85 & 1.69 & 0.39 & 0.51 & 1.87 \\
$\mathbf{1 5 0 0}$ & 37.90 & 21.30 & 16.13 & 14.83 & 3.12 & 1.55 & 0.61 & 0.84 & 3.72 \\
$\mathbf{1 6 0 0}$ & 44.50 & 23.55 & $\mathbf{N D}$ & 19.46 & 4.24 & 1.44 & 0.67 & 0.93 & 4.81 \\
\hline
\end{tabular}


Table 3. Chemical composition of reformed slag according to the timeslot at $1600{ }^{\circ} \mathrm{C}$.

\begin{tabular}{cccccccccccccc}
\hline \multirow{2}{*}{$\begin{array}{c}\text { Reaction Time, } \\
\text { min }\end{array}$} & $\mathbf{S i O}_{\mathbf{2}}$ & $\mathbf{C a O}$ & $\mathbf{F e}_{\mathbf{2}} \mathbf{O}_{\mathbf{3}}$ & $\mathbf{A l}_{\mathbf{2}} \mathbf{O}_{\mathbf{3}}$ & $\mathbf{M g O}$ & $\mathbf{N a}_{\mathbf{2}} \mathbf{O}$ & $\mathbf{Z n O}$ & $\mathbf{M n O}$ & $\mathbf{C r}_{\mathbf{2}} \mathbf{O}_{\mathbf{3}}$ & $\mathbf{P}_{\mathbf{2}} \mathbf{O}_{\mathbf{5}}$ & $\mathbf{K}_{\mathbf{2}} \mathbf{O}$ & $\mathbf{T i O}_{\mathbf{2}}$ & $\mathbf{S O}_{3}$ \\
\hline $\mathbf{5}$ & 35.94 & 21.26 & 19.55 & 11.19 & 3.53 & 2.39 & 2.01 & 1.45 & 1.0 & 0.87 & 0.77 & - & - \\
$\mathbf{1 0}$ & 39.05 & 22.56 & 14.32 & 12.53 & 3.69 & 1.93 & 0.57 & 1.43 & 1.21 & 0.72 & 0.86 & 1.09 & - \\
$\mathbf{1 5}$ & 42.45 & 25.55 & 8.68 & 12.97 & 4.46 & 1.98 & - & 1.86 & 1.17 & 1.17 & 0.85 & - & - \\
$\mathbf{2 0}$ & 44.92 & 26.11 & 4.47 & 14.35 & 4.09 & 2.14 & - & 1.51 & 0.72 & - & 1.02 & - & 0.61 \\
$\mathbf{2 5}$ & 46.24 & 26.56 & 2.69 & 14.48 & 3.88 & 2.55 & - & 1.62 & 0.75 & - & - & 0.99 & - \\
$\mathbf{3 0}$ & 46.25 & 26.57 & $\mathbf{N D}$ & 14.49 & 3.92 & 2.70 & - & 1.70 & 1.25 & 0.90 & 0.99 & 0.72 & 0.50 \\
\hline
\end{tabular}

Table 4 shows EDS results of the chemical composition of the pig iron separated from copper smelting slag by high temperature reduction according to the change of the reaction temperature condition. It was confirmed that there was no significant difference according to the changes of the reaction temperature conditions, and it contained about $86 \% \mathrm{Fe}$ and $3 \% \mathrm{Cu}$, indicating the formation of ferrous alloy contained $\mathrm{Cu}$.

Table 4. Chemical composition of the pig iron separated from copper smelting slag by high temperature reduction according to the changes of reaction temperature condition analyzed by EDS.

\begin{tabular}{ccccccc}
\hline \multirow{2}{*}{ Reaction Temperature, ${ }^{\circ} \mathbf{C}$} & \multicolumn{6}{c}{ Element, \% } \\
\cline { 2 - 7 } & $\mathbf{S i}$ & $\mathbf{C}^{*}$ & $\mathbf{C r}$ & $\mathbf{M n}$ & $\mathbf{C u}$ & $\mathbf{F e}$ \\
\hline $\mathbf{1 4 0 0}$ & 5.53 & 3.84 & 1.33 & 1.43 & 3.11 & 84.75 \\
$\mathbf{1 5 0 0}$ & 4.09 & 4.00 & 0.99 & 1.12 & 3.62 & 86.17 \\
$\mathbf{1 6 0 0}$ & 2.94 & 4.62 & 1.25 & 0.81 & 2.93 & 87.45 \\
\hline
\end{tabular}

Cast iron is widely used in multicomponent ferrous alloy in place of steel at considerable low cost and with optimum combination properties such as castability, machinability, and excellent wear resistance, and has high hardness and high inherent damping capabilities [19-21]. It is known that the addition of alloy elements, cooling rate and formation of graphite influence the properties of cast iron. Copper leads to the graphitizing and pearlitization of cast iron, which are phase-stabilizing, which substantially affects mechanical properties such as strength, toughness and corrosion resistance [19-24]. Many researchers have studied the effect of $\mathrm{Cu}$ addition on the mechanical properties and structure formation of cast iron. Nassef et al. [19], Agunsove et al. [20] and Razumakov et al. [23] concluded that the structure and mechanical properties of cast iron are affected by the addition of 1 to $3.5 \%$ copper, which resulted in better wear resistance and the lowest wear loss, and hardness and tensile strength initially increased according to the decreased to volume fraction of graphite and stabilization of pearlite. Cast iron contains such main elements as carbon ranging from 1.8 to $4 \%$ and silicon from 1 to $3 \%$, and other alloying elements, and has graphite flakes. In carbothermal reduction smelting, the recovered ferrous alloys appeared as cast iron according to the content-ranges of $\mathrm{C}$ and $\mathrm{Si}$, which represented about $4.1 \%$ and $4.18 \%$, respectively, in the ferrous alloys recovered from the copper slag. Consequently, it was considered that the recovered ferrous alloy can be used in place of cast iron ingots.

In reduction smelting by solid carbon, iron is completely reduced and forms liquid pig iron at $1600{ }^{\circ} \mathrm{C}$ for $30 \mathrm{~min}$. The reformed slag contains about $46 \% \mathrm{SiO}_{2}, 26 \% \mathrm{CaO}$ and $14 \% \mathrm{Al}_{2} \mathrm{O}_{3}$, and is an acid slag. Therefore, the next experiment with the addition of $\mathrm{CaO}$ was conducted to change the chemical composition of reformed slag with the ratio $\mathrm{B}=\% \mathrm{CaO} / \% \mathrm{SiO}_{2}=0.8,0.9,1.0,1.1$ and 1.2 at a temperature of $1600^{\circ} \mathrm{C}$ for $30 \mathrm{~min}$.

As with reduction smelting with addition of $\mathrm{CaO}$, the fayalite $\left(2 \mathrm{FeO} \cdot \mathrm{SiO}_{2}\right)$ in the copper slag is decomposed in a high temperature and reduction process, and iron oxide is reduced and separated from the liquid pig iron according to reactions (1) to (5) in order. In this case, it might be seen that the remaining oxides such as the $\mathrm{SiO}_{2}, \mathrm{CaO}, \mathrm{Al}_{2} \mathrm{O}_{3}$ and $\mathrm{MgO}$ interact with each other, and hence generate 
the reformed slag. This reformed slag might consist of typically eutectic compounds such as $\mathrm{CaO} \cdot \mathrm{SiO}_{2}$, $2 \mathrm{CaO} \cdot \mathrm{SiO}_{2}, 3 \mathrm{CaO} \cdot 2 \mathrm{SiO}_{2}, \mathrm{CaO} \cdot \mathrm{Al}_{2} \mathrm{O}_{3} \cdot 2 \mathrm{SiO}_{2}, 2 \mathrm{CaO} \cdot \mathrm{Al}_{2} \mathrm{O}_{3} \cdot \mathrm{SiO}_{2}, \mathrm{CaO} \cdot \mathrm{MgO} \cdot \mathrm{SiO}_{2}$, etc. $[25,26]$. The basic slag with a high content of $\mathrm{CaO}$ transforms into calcium silicates slag by the addition of $\mathrm{CaO}$, and hence changing the chemical compositions of the slag may be effectively conducted in the reducing process. The chemical composition of the slag reformed from copper slag in the reduction smelting with addition of $\mathrm{CaO}$ was determined by $\mathrm{X}$-ray fluorescence (XRF) to evaluate the difference according to the addition of $\mathrm{CaO}$, as shown in Table 5. As the XRF results show, it was found that the $\mathrm{SiO}_{2}$ content in the slag decreased according to the increase in $\mathrm{CaO}$ content. Table 6 shows EDS results of the chemical composition of the pig iron separated from copper smelting slag by high temperature reduction according to that of the addition of $\mathrm{CaO}$. It was again confirmed that there was no significant difference according to the addition of $\mathrm{CaO}$, and it contained about $86 \%$ of $\mathrm{Fe}$ and $3 \%$ of $\mathrm{Cu}$, indicating the formation of ferrous alloy contained $\mathrm{Cu}$.

Table 5. Chemical composition of reformed slag analyzed by XRF.

\begin{tabular}{|c|c|c|c|c|c|c|c|c|c|c|c|c|c|}
\hline \multirow{2}{*}{ Type } & & \multicolumn{12}{|c|}{ Element, \% } \\
\hline & & $\mathrm{SiO}_{2}$ & $\mathrm{CaO}$ & $\mathrm{Al}_{2} \mathrm{O}_{3}$ & $\mathrm{MgO}$ & $\mathrm{Na}_{2} \mathrm{O}$ & $\mathrm{TiO}_{2}$ & $\mathrm{~K}_{2} \mathrm{O}$ & $\mathrm{MnO}$ & $\mathrm{SO}_{3}$ & $\mathrm{BaO}$ & $\mathrm{Fe}_{2} \mathrm{O}_{3}$ & $\mathrm{SrO}$ \\
\hline \multirow{5}{*}{$\begin{array}{l}\mathrm{CaO} \text { addition, } \mathrm{g} \text { per } \\
100 \mathrm{~g} \text { of copper slag }\end{array}$} & 5 & 40.05 & 37.50 & 13.45 & 5.00 & 1.52 & 0.91 & 0.635 & 0.61 & 0.30 & - & - & - \\
\hline & 10 & 37.42 & 42.54 & 13.12 & 4.40 & 0.54 & 0.41 & 0.18 & 0.23 & 0.28 & 0.66 & 0.10 & 0.07 \\
\hline & 15 & 31.80 & 50.86 & 12.42 & 4.14 & - & .0 .24 & - & - & 0.46 & - & - & 0.08 \\
\hline & 20 & 28.82 & 53.94 & 11.80 & 3.49 & - & 0.21 & - & - & 0.45 & 0.49 & 0.70 & 0.07 \\
\hline & 25 & 22.36 & 60.91 & 11.24 & 3.50 & - & - & - & - & 0.55 & - & 1.14 & - \\
\hline
\end{tabular}

Table 6. Chemical composition of the pig iron separated from copper slag.

\begin{tabular}{cccccccc}
\hline \multirow{2}{*}{ CaO Addition, g per 100 g of Copper Slag } & \multicolumn{5}{c}{ Element, \% } \\
\cline { 2 - 7 } & $\mathbf{S i}$ & $\mathbf{C}$ & $\mathbf{C r}$ & $\mathbf{M n}$ & $\mathbf{C u}$ & $\mathbf{F e}$ \\
\hline $\mathbf{5}$ & 4.56 & 3.95 & 1.12 & 1.82 & 3.01 & 85.54 \\
$\mathbf{1 0}$ & 4.10 & 4.09 & 1.03 & 1.56 & 3.17 & 86.05 \\
$\mathbf{1 5}$ & 4.23 & 4.35 & 1.25 & 1.27 & 3.19 & 85.71 \\
$\mathbf{2 0}$ & 3.63 & 3.95 & 0.87 & 1.30 & 3.06 & 87.19 \\
$\mathbf{2 5}$ & 2.94 & 4.62 & 1.25 & 0.81 & 2.93 & 87.45 \\
\hline
\end{tabular}

Portland cement is manufactured with a closely controlled chemical combination of $\mathrm{Ca}, \mathrm{Si}, \mathrm{Al}, \mathrm{Fe}$ and other ingredients, and common materials for cement include limestone, shells, and chalk or marl combined with shale, clay, blast furnace slag, silica sand, and iron ore. Blast furnace slag (BFS) is one of the massive raw materials acquired through Portland blast furnace slag cement (PBFSC) because BFS has a similar chemical composition with the chemical composition of Portland cement [27-30]. The general chemical composition of $\mathrm{BFS}$ is about 32 to $40 \% \mathrm{SiO}_{2}, 32$ to $50 \% \mathrm{CaO}, 7$ to $16 \% \mathrm{Al}_{2} \mathrm{O}_{3}$ and 5 to $10 \% \mathrm{MgO}$, etc. For the manufacture of Portland cement, limestone as the principal raw material is burned at a high temperature causing air pollution, which creates large $\mathrm{CO}_{2}$ emissions, therefore, BFS was discovered a partial replacement in raw material of Portland cement as PBFSC could be a kind of eco-friendly cement that emits about $40 \%$ less $\mathrm{CO}_{2}$ than Portland cement supported by the Green Purchasing law $[29,30]$. South Korea has also used BFS as a replacement for the raw material of Portland cement and it is widely employed in civil engineering structures due to its eco-friendly processing and lower cost of PBFSC. The qualities of PBFSC are specified in KS L 5210: Blast furnace slag cement of Korean standard has three types such as 1 type is over 5, less than 30 of BFS ratio, 2 types (over 30, less than 60) and 3 type (over 60, less than 70). In 2017, the BFS has been generated about 16 million tons a year, and 92\% of BFS used in cement industry [31].

In the present study, it was observed that reformed slag from copper slag for iron recovery was similar to BFS. When the addition of $\mathrm{CaO}$ are up to $15 \%$, the chemical composition of reformed slag is to that of BFS. Chemical analysis of both the produced slag and BFS showed that major oxides such as 
$\mathrm{CaO}, \mathrm{SiO}_{2}, \mathrm{MgO}$ and $\mathrm{Al}_{2} \mathrm{O}_{3}$ comprised about $95 \%$ of the total in accordance with the requirements of BFS as cement material, as shown in Table 5.

\subsection{Mineralogical Analysis of Reformed Slags}

The cooling method affects the crystallization of slag as rapid cooling tends to form a glassy non-crystalline material and slower cooling leads to the crystallization of several slag minerals such as akermanite, gehlenite, wollastonite, dicalcium silicate, anorthite, etc. [32]. The mineralogical composition of reformed slag was obtained by identification of precipitated crystalline phases with powder X-ray diffraction analysis (XRD). As shown in Figure 4, glass and quartz phases were presented in the slag sample without addition of $\mathrm{CaO}$, and the slag was like glass. When the $\mathrm{CaO}$ addition was $5 \%$, diffraction peaks of the glass-like slag were not detected and the glass matrix was transformed into diopside aluminian $\mathrm{Ca}(\mathrm{Mg})(\mathrm{Al}, \mathrm{Si}) \mathrm{SiO}_{7}$ and akermanite-gehlenite series $\mathrm{Ca}_{2}(\mathrm{Al}, \mathrm{Mg})(\mathrm{Si}, \mathrm{Al}) \mathrm{SiO}_{7}$ phases, indicating that glass slag was completely formed in calcium silicate phases. For slag with $10 \%$ $\mathrm{CaO}$, akermanite-gehlenite series still appeared, but diopside aluminian was transformed to calcium aluminosilicate $\mathrm{Ca}_{2} \mathrm{Al}_{2} \mathrm{SiO}_{7}$. When the addition of $\mathrm{CaO}$ was 15 and $20 \%$, only akermanite-gehlenite series was observed, but when the added $\mathrm{CaO}$ was of $25 \%$, diffraction peaks of gehlenite still appeared, while dicalcium silicate $\mathrm{Ca}_{2} \mathrm{SiO}_{4}$ was also observed. This indicates that dicalcium silicate phases are produced due to increase in $\mathrm{CaO}$ content. To summarize, glass-like slag can be greatly transformed into new phases as calcium silicate when addition of $\mathrm{CaO}$ is above $5 \%$.

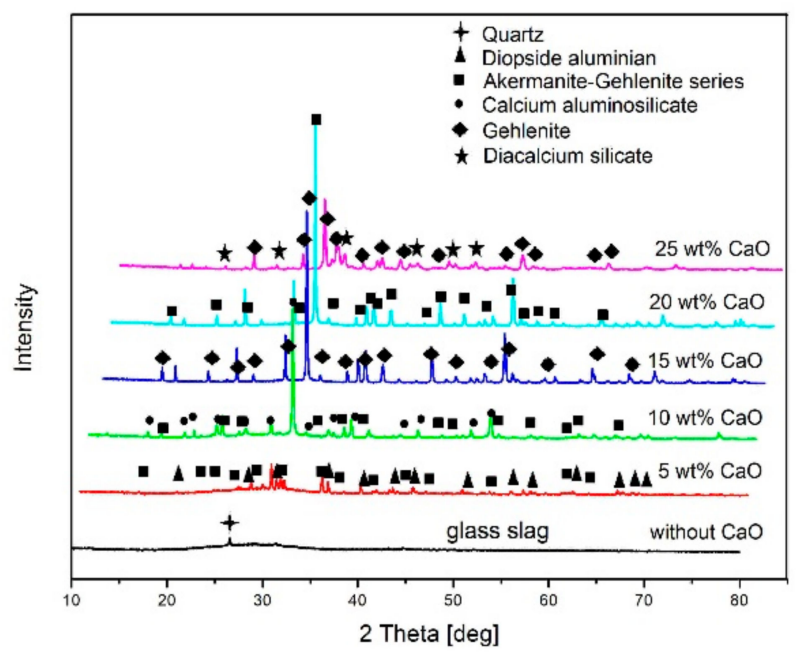

Figure 4. XRD patterns of reformed slag with and without addition of $\mathrm{CaO}$.

\subsection{Zinc ash Characterization}

During reduction smelting, the zinc oxide in copper slag can be easily reduced and removed with fumes from the furnace. It was confirmed that there was no detected zinc content in the reformed slag after $10 \mathrm{~min}$ in the reduction smelting experiment, as shown in Table 3. In this study, there were two types of zinc ash generated during reduction smelting due to reduction smelting performed with and without addition of $\mathrm{CaO}$. Table 7 shows the compositions of zinc ash powder. It was found to be contaminated with main impurities such as $\mathrm{Ca}, \mathrm{Fe}, \mathrm{Si}$ and $\mathrm{Pb}$. The amount of zinc in zinc ash powder generated during reduction smelting was found to be rich at a rate of 52 to $81 \%$. This level is like the concentrates of zinc employed for the primary production of zinc [33,34]. Figure 5 shows the $X R D$ patterns of the zinc ash powder which indicates that the zinc in the zinc ash generated during reduction smelting without addition of $\mathrm{CaO}$ is in the form of $\mathrm{ZnO}$, and a few points of metallic zinc were observed, as shown in Figure 5a. However, the zinc ash generated during reduction smelting with addition of $\mathrm{CaO}$ contained several impurities such as calcium oxide, calcium carbonate and calcium lead as shown in Figure 5b. 
Table 7. Chemical composition of zinc ash powder analyzed by XRF.

\begin{tabular}{cccccccccc}
\hline Element, $\%$ & $\mathbf{Z n}$ & $\mathbf{P b}$ & $\mathbf{S i}$ & $\mathbf{F e}$ & $\mathrm{Al}$ & $\mathbf{K}$ & $\mathrm{S}$ & $\mathrm{Ca}$ & $\mathbf{M n}$ \\
\hline $\begin{array}{c}\text { Zinc ash generated during reduction } \\
\text { smelting with addition of } \mathrm{CaO}\end{array}$ & 81.4 & 5.26 & 4.46 & 2.89 & 1.90 & 1.40 & 1.20 & 0.73 & 0.68 \\
$\begin{array}{c}\text { Zinc ash generated during reduction } \\
\text { smelting with addition of } \mathrm{CaO}\end{array}$ & 51.9 & 1.31 & 4.63 & 2.32 & 2.64 & 1.10 & 0.77 & 35.3 & - \\
\hline
\end{tabular}

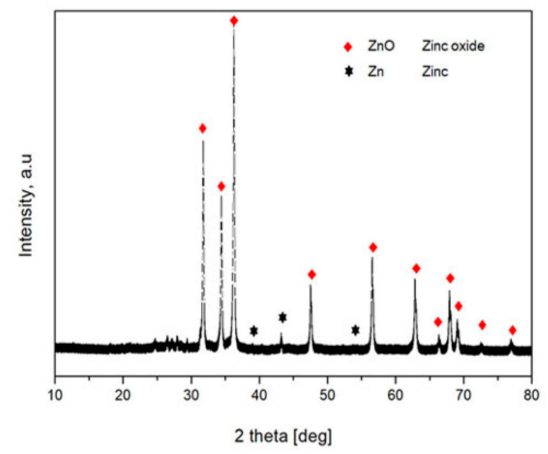

(a)

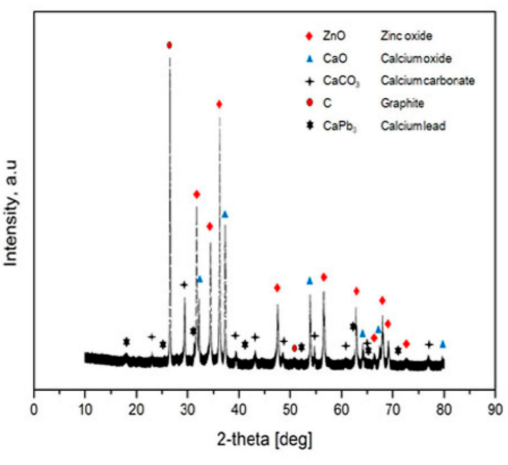

(b)

Figure 5. XRD patterns of the zinc ash powder generated during reduction smelting; (a) without addition of $\mathrm{CaO}$, and (b)-with addition of $\mathrm{CaO}$.

\section{Conclusions}

Copper smelting slag contains a significant amount of iron, copper and zinc, which are able to be recovered using a pyrometallurgical process to obtain final products which can be utilized. The feasibility of high-temperature reduction technology to improve the benefits of metallic elements and reformed slag from copper slag using reduction smelting was investigated. The recovered ferrous alloy with about $3 \%$ of copper can be used in place of cast iron ingots for excellent casting alloys that have significant properties including strength, toughness, corrosion resistance, etc. The reformed slag with addition of about $15 \% \mathrm{CaO}$ is possible to utilize in replacement of a raw material for Portland cement. On the other hand, the furnace dust which contained a high content of zinc can be used in the primary production of zinc. It was confirmed that a high-temperature reduction smelting does not generate any residuals, as the waste, and all final products from the process are value-added useable.

Author Contributions: U.E. organized the study plan, performed the experiments, and J.-P.W. reviewed and checked the manuscript. All authors have read and agreed to the published version of the manuscript.

Funding: This research received no external funding.

Acknowledgments: This work was supported by the National Research Foundation of Korea (NRF) grant funded by the Korea government (MSIT) (No. 2019R1F1A1049405) and was supported by the BB21+ Project in 2019.

Conflicts of Interest: The authors declare no conflict of interest.

\section{References}

1. Gorai, B.; Jana, R.K. Characteristics and Utilization of Copper Slag. Resour. Conserv. Recy. 2002, 39, $299-313$. [CrossRef]

2. Erdenebold, U.; Choi, M.H.; Wang, J.P. Recovery of pig iron from coper smelting slag by reduction smelting. Arch. Metall. Mater. 2018, 63, 1793-1798.

3. Ji, S.W.; Seo, C.H. The application of copper smelting slag as concrete aggregate. J. Korean Inst. Resour. Recyc. 2006, 2, 68-72.

4. Wang, J.P.; Hwang, K.M.; Choi, H.M. A Study on the Recovery of Iron from Copper Slag with Temperature. Indian J. Appl. Res. 2018, 2, 977-982. 
5. Wang, J.P.; Hwang, K.M. Manufacture of foundry pig iron from copper smelting slag. Indian J. Appl. Res. 2018, 2, 973-976.

6. Busolic, D.; Parada, F.; Parra, R.; Sanchez, M.; Palacios, J.; Hino, M. Recovery of iron from copper flash smelting slags. Miner. Process. Ext. Met. 2011, 120, 32-36. [CrossRef]

7. Heo, J.H.; Kim, B.S.; Park, J.H. Effect of CaO Addition on Iron Recovery from Copper Smelting Slag by Solid Carbon. Metall. Mater. Trans. B 2013, 44, 1352-1363. [CrossRef]

8. Sanchez, M.; Parada, F.; Parra, R.; Marquez, F.; Jara, R.; Carrasco, J.C.; Palacios, J. Management of Copper Pyrometallurgical slags: Giving additional value to copper mining industry. In Proceedings of the International VII International Conference on Molten Slags Fluxes and Salts, Cape Town, South Africa, 25-28 January 2004; The South African Institute of Mining and Metallurgy: Johannesburg, South Africa, 2004; pp. 543-550.

9. Sarfo, P.; Wyss, G.; Ma, G.; Das, A. Carbothermal Reduction of Copper Smelter Slag for Recycling into Pig Iron and Glass. Miner. Eng. 2017, 107, 8-19. [CrossRef]

10. Yuksel, U.; Tegin, I. Recovery of Copper and Cobalt from Copper Slags as Selective. J. Environ. Eng. Sci. 2017, 6, 388-394. [CrossRef]

11. Liao, Y.; Zhou, J.; Huang, F. Separating and recycling of $\mathrm{Fe}, \mathrm{Cu}, \mathrm{Zn}$ from dumped copper slag by microwave irradiation assisted carbothermic method. J. Residuals Sci. Technol. 2016, 13, 155-160. [CrossRef]

12. Guo, Z.; Zhu, D.; Pan, J.; Wu, T.; Zhang, F. Improving benefication of copper and iron from copper slag by modifying the molten copper slag. J. Met. 2016, 6, 86 .

13. Long, H.; Meng, Q.; Chun, T.; Wang, P.; Li, J. Preparation of metallic iron powder from copper slag by carbothermic reduction and magnetic separation. Can. Metall. Quart. 2016, 55, 339-344. [CrossRef]

14. Xian-Lin, Z.; De-Qing, Z.; Jian, P.; Teng-Jiao, W. Utilization of waste copper slag to produce directly reduction iron for weathering resistant steel. ISIJ Int. 2015, 55, 1347-1352. [CrossRef]

15. Lykasov, A.A.; Ryss, G.M.; Sharafutdinov, D.G.; Pogodin, A.Y. Extraction of iron from copper-plant slag. Steel Transl. 2016, 46, 609-613. [CrossRef]

16. Cao, Z.; Sun, T.; Xue, X.; Liu, Z. Iron recovery from discarded copper slag in a RHF direct reduction and subsequent grinding/magnetic separation process. Minerals 2016, 6, 119. [CrossRef]

17. Shaban, A.; Ahmed, E.; Hanan, K.; Jaber Abu, Q. Wear behavior of grey cast iron with the of copper addition. Adv. Mech. Eng. 2018, 10,1-8.

18. Gumienny, G.; Kacprzyk, B. Effect of Copper on the Crystallization Process, Microstructure and Selected Properties of CGI. Arch. Foundry. Eng. 2017, 17, 51-56. [CrossRef]

19. Nassef, A.E.; El-Nas, A.A.; Raya, G.A. Influence of Copper Additions and Cooling Rate on Mechanical and Tribological Behavior of Grey Cast Iron. In Proceedings of the 7th International Saudi Engineering Conference (SEC7), KSA, Riyadh, Saudi Arabia, 2-5 December 2007; pp. 307-318.

20. Agunsoye, J.O.; Bello, S.A.; Hassan, S.B.; Adeyemo, R.G.; Odii, J.M. The effect of copper addition on the mechanical and wear properties of grey cast iron. J. Miner. Mater. Character. Eng. 2014, 2, 470-483. [CrossRef]

21. Sarkar, T.; Sutradhar, G. Microstructure and mechanical properties of copper alloyed austempered grey cast iron. Can. Metall. Quart. 2019, 58, 46-55. [CrossRef]

22. Sil'Man, G.I.; Kamynin, V.V.; Tarasov, A.A. Effect of copper on structure formation in cast iron. Met. Sci. Heat. Treat. 2003, 45, 254-258. [CrossRef]

23. Razumakov, A.A.; Stepanova, N.V.; Bataev, I.A.; Lenivtseva, O.G.; Riapolova, I.I.; Emurlaev, K.I. The structure and properties of cast iron alloyed with copper. In Proceedings of the 2015 International Conference on Mechanical Engineering, Automation and Control Systems (MEACS), Tomsk, Russia, 1-4 December 2015; Tomsk Polytechnic University: Tomsk, Russia; Volume 124, pp. 757-760.

24. Konca, E.; Tur, K.; Koç, E. Effect of alloying elements (Mo, Ni and Cu) on the austemperability of GGG-60 ductile cast iron. Metals 2017, 7, 320. [CrossRef]

25. Morey, G.W. Phase-Equilibrium Relations of the Common Rock-Forming Oxides Except Water. In Micheal Fleischer, Data of Geochemistry; United States Government Printing Office: Washington, DC, USA, 1964; pp. 54-76.

26. Verlag Stahleisen, D. Dusseldorf. In Slag atlas, 2nd ed.; European Communities: Dusseldorf, Germany, 1995; pp. 99-136.

27. Rahman, A.A.; Abo-El-Enein, S.A.; Aboul-Fetouh, M.; Shehata, K. Characteristics of Portland Blast Furnace Slag cement containing cement ciln dust and active silica. Arab. J. Chem. 2016, 9, 8138-8143. 
28. Angulo-Ramírez, D.E.; de Gutiérrez, R.M.; Puertas, F. Alkali-activated Portland Blast Furnace Slag Cement: Mechanical properties and hydration. Constr. Build. Mater. 2017, 140, 119-128. [CrossRef]

29. Maeda, Y. Slag cement-related products which utilized a property of the Ground Granulated Blast Furnace Slag. Nippo Steel Sumitomo Metal Tech. Rep. 2015, 109, 114-118.

30. Ueki, Y. History and utilization of Portland Blast Furnace Slag Cement. Nippo Steel Sumitomo Metal Tech. Rep. 2015, 109, 109-113.

31. Steel and Metal news. Available online: https://www.snmnews.com/news/articleView.html?idxno= 447525 (accessed on 5 June 2019).

32. Aimi Noorliyana, H.; Mohd Mustafa Al Bakri, A.; Azira, M.N.; Mariamadzliza, N.; Nan, M.; Kamrosni, A.R.; Kamarudin, H. Alkali Activated Blast Furnace Slag Cement. Adv. Environ. Biol. 2013, 7, 3713-3715.

33. Wojciech, H.; Konrad, K.; Dariusz, R. Selective recovery of zinc from metallurgical waste materials from processing zinc and lead ores. Molecules 2019, 24, 1-10.

34. Siwiec, G.; Sozańska, M.; Blacha, L.; Smalcerz, A. Behaviour of iron during reduction of slag obtained from copper flash smelting. Metalurgija 2015, 54, 113-115.

(C) 2020 by the authors. Licensee MDPI, Basel, Switzerland. This article is an open access article distributed under the terms and conditions of the Creative Commons Attribution (CC BY) license (http://creativecommons.org/licenses/by/4.0/). 